\title{
FROM ONCE READ TO TWICE PERFORMED: EXPLORING THE QUESTIONS OF PERFORMATIVITY AND RASA IN MODERN INDIAN DRAMA
}

\section{Dr. Anshu Surve}

\begin{abstract}
Recognising, analysing, and theorising the convergence and collapse of clearly demarcated realities, hierarchies, and categories is at the heart of postmodernism: this premise is at the core of this article when mediating two distinctive theories of criticism. The paper is drawn on the dualitatem of the critical theories of Performativity and Rasa with the objective of initiating deliberations and debates on Indian Aesthetics. Performance studies as an interdisciplinary discourse uses performance as a lens to engage with social, political, religious questions. The Rasa Theory in Indian dramaturgy and aesthetics have been critically analysed and applied on quite a few western and Indian literary works but seldom has a literary work been critically studied through the dual critical lenses of performativity in relation to the Rasa experience. Rasa is a manifestation of emotions translated to the audience in the form of shared experience. The proposed research is a humble attempt to engage with the questions: How performance of a drama and its affective experience can be attributed to the Rasa experience? This interdisciplinary research is contextualised in modern drama where in the complex matrix of performance, its affect becomes a shared Rasa experience that resonates in the form of a narrative with binaries of universality and subjectivity.
\end{abstract}

Keywords: Performance, Rasa, Indian Aesthetics, and Postmodernism

Bharata, the father of Indian dramaturgy and his treatise Natvasastra composed in 2nd century B.C. referred to as the pivot of Sanskrit literary thought and theory literary theory is considered as an additional Veda. The poetics of Indian aesthetics, a distinctive philosophical and spiritual theory on art, and literature posits Rasa as an 
essential state of mind in a dominating schema of spontaneous emotional surgency and reactivity to a form of art. The Natvasastra in its entirety is not devoted only to the elucidation of rasa but is the compendium of aesthetic and philosophic context within which rasa was originally formulated. Bharata propounded Rasas in the formserotic, comic, pathetic, furious, heroic, terrible, odious and marvellous, all instilling aesthetic experience. Bharata's theory of Rasa, was furthered Abhinavagupta, who widened its scope to varieties of theatre and poetry. The theory significantly evolved with another exponent of Aesthetics - Ãndandavardhana who added a new rasa - the ninth rasa and called it shānta-rasa attributed to peace and quietist emotional space.

For Bharata, the drama performed on the stage existed as a type of temporal gamut where the dramatist, the director and the actors come together to create the drama, which the audience responds and reacts to. The generation of rasa takes place at the end of the first process i.e. creation, the second process of appreciation then begins with the discerning of rasa. Thus, rasa is a component of a process that becomes apparent in and through the form of drama expressed. A rasa is recognised as the state of relishing a permanent disposition-the sthayibhava which is attainable by the interaction between on it of attendant emotional conditions Vibhavas, Anubhavas and Sanchari/ Vyabhichari bhavas. Anubhava, signifies, that the ensuants or effects following the rise of the emotions. Abhinavagupta did not view rasa and dhvani as identical terms, rather believed that these two theories supplemented each other and that they represented two important aspects of Indian aesthetic theory. He further emphasizes that "rasāh dhvanih eva" which means, rasa and dhvani have to be taken together because the eva stands for inseparability rather than identification. Professor S.S. Barlingay asserts that rasa and dhvani are like a symbol and its meaning, and that Abhinavagupta sought to negate thrash this distinction between symbolic presentation and meaning. Another important feature of Abhinavagupta's aesthetic theory is his explanation of the experience of rasa itself. Abhinavagupta affirms with the understanding of rasa as relish or delight.

Considering that depersonalisation and universalisation had always been dear to both the Indian and the western exponents of criticism, when Aristotle's theory of catharsis is placed in tandem with the theory of Sadhanikarana of Rasa experience, 
the common understood premise is that both exercise over emotions. For Abhinavagupta the poetic experience is never personal or individual it is always universal. All personal experience is limited and the feeling of limitation is by itself a painful experience. But when it transcends personal limits and is universal i.e. become that common experience of all the receptive and responsive reader or playgoers, it is converted into a veritable pleasure i.e. pity and fear are both enjoyed because the feeling of universality is always pleasant. In an attempt to connect commonalities and shared cords between the east and the west, contemplating on Aristotle's theory of Catharsis which propounds that the theory of Catharsis' demonstrates that wholesome influence of poetry in general and tragedy in specificity is exercised over emotions. Indian concept of Sadharanikaran and the Aristotelian concept of Catharsis can be posited on these shared grounds. On these common grounds, Sadharanikaran, the healthy influence which poetry in general, and tragedy, in particular exercise over emotions evoking rasanubhava or relish of emotions comes forth as a process of attaining Rasanubhava or the aesthetic delight. Dryden in his treatise emphasized that poetry must delight, but at the same time, it must also appreciate beauty advocating on the shared grounds of Aristotle that delight is the main attainment. Instruction is secondary and delight, the first, the primary function of poetry and a bare imitation will not serve the ends of poetry. It is only such aesthetic delight that has the power to move, the power to transport, the power to affect the soul, and excite the passions and above lead to reactivity and response that may be universal or subjective at the same time depending on the socio-cultural contexts.

According to Dryden, "Literature is not static, but a dynamic process, it is ever growing and changing and the rules and literary judgements also must as a consequence, change accordingly". The definition and understanding of drama as evergrowing and dynamic has consequentionalised a major contention that Richard Schechner asserted: drama is not merely a province of the stage, but of everyday life, and is a cross-cultural phenomenon. A performance in the words of Erving Goffman may be defined as all the activity of a given participant on a given occasion which serves to influence in any way any of the other participants. Taking a particular participant and his performance as a basic point of reference, we may refer to those who contribute to the other performances as the audience, observers, or co- 
participants. The pre-established pattern of action which is unfolded during a performance and which may be presented or played through on other occasions may be called a "part" or a "routine." These situational terms can easily be related to conventional structural ones. When an individual or performer plays the same part to the same audience on different occasions, a social relationship is likely to arise. Defining social role as the enactment of rights and duties attached to a given status, we can say that a social role will involve one or more parts and that each of these different parts may be presented by the performer on a series of occasions to the same kinds of audiences or to an audience of the same persons. Modern drama and the plays of Vijay Tendulkar, Mahesh Dattani and other playwrights are contextualised in the same premise. 'It is important to develop and articulate theories concerning how performances are generated, transmitted, received and evaluated in pursuit of these goals, performance studies is insistently intercultural, inter-generic and inter-disciplinary'. (Schechner,2002) This narrative emphasizes a definition of performance as being "between theatre and anthropology"(the study of human beings through time and space in relation to characters, social relations and culture) and often stressing the importance of intercultural performances. The nature of performance theory is demonstrated by its all-encompassing, even holistic, approach to theatre and performance, with popular culture, folklore, and ethnic diversity incorporated into the cross-disciplinary mix. The literary partner of the word 'performance' is 'performative' and was introduced by J.L Austin, a linguistic philosopher, who coined the term for the first-time during lectures at Harvard University in 1955. As Austin put it, 'to say something is to do something'. (Austin, 1962) 'Performativity' as a concept is closely related to postmodernism where in the idea of 'performance' is not seen as intrinsically artistic or theatrical, but as something that pervades the fabric of the social, political and material world. It is an inalienable part of what constitutes power and knowledge. The concept of 'performing in everyday life' is a central aspect of performativity, as envisaged by Schechner. 'Performativity is everywhere - in daily behaviour, in the professions, on the internet and media, in the arts and in the language'. The implication is that many individuals, going about their 'everyday businesses' are not being themselves all of the time. They are acting out roles, predetermined to the point of being programmed in some cases. 'Performing in everyday life involves people in a wide range of activities from solo or intimate performances behind closed doors to small group 
activities to interacting as part of a crowd.' (Schechner, 2002). This further indicates that the actor can draw on his/her own experience, be it of a personal kind (i.e. they may have previously been a teacher) or from memories and observations based on an actual person, or persons. (E.g. a teacher who had taught them).

Performance studies incorporates theories of drama, dance, art, anthropology, folklores, philosophy, cultural studies, psychology, sociology, comparative literature, communication studies and music performance. It asserts the importance of different systems of transformations which vary enormously from culture to culture and throughout historical periods and movements. Prompted by the theory of performance, the literary discussion of drama, in the past two decades has developed a sophisticated approach to all varieties of performances, a critical vocabulary for considering the interplay between the scripted drama and the (actual, implied, or imagined) practices of stage performance. Flourishing in an ambiguous tension with theatre studies and drama studies, performance studies now traces the horizon of an energetically expanding field characterized by a range of aims, methods, and objects of inquiry. Another important premise of performance theory is that it is not the text that prescribes the meanings of the performance: it is the construction of the text within the specific apparatus of the ceremony that creates performative force. Performing reconstitutes the text; it does not echo, give voice to, or translate the text.

The question then arises: How can performance and performativity contribute in mediating with the process of attainment of Aesthetic experience: the rasanubhava or the aesthetic relish? How might a rethinking of drama reinvigorate a way of exploring-not prescribing-the possibilities of performance and rasa experience? I (The God Brahma) have created the Natyaveda to show good and bad actions and feelings of both the gods and yourselves. It is a representation of the entire three worlds and not only of the gods or of yourselves. Dharma, artha, kama, humor, fights, greed, now killing, Natya teaches right to people going wrong; it gives enjoyment for those who are pleasure seekers; it chastises those who are illbehaved and promotes tolerance in the well-behaved. It gives courage to cowards, energy to the brave. It enlightens people of little intellect and gives wisdom to the wise. Natya provides entertainment to kings, fortitude to those grief stricken, money 
to those who want to make a living, and stability to disturbed minds. Natya is a representation of the ways of the world involving various emotions and differing circumstances. It relates the actions of good, bad, and middling people, giving peace, entertainment, and happiness, as well as beneficial advice, to all. It brings rest and peace to persons afflicted by sorrow, fatigue, grief, or helplessness. There is no art, no knowledge, no learning, no action that is not found in Natya (Natya Shashtra, Chapter 1).

During performance characters along with theatrical nuances act as a charioteer of emotions i.e. the emotions evoked in the performer (actor/character)are being shared as an emotional experience for the audience of the performance and this shared emotional experiences at the heart of emotionally charged event are states experienced as influence attributed to some cause in the past spawn reflexes, perception, cognition, and behaviour in the form of prototypical/exemplary/representational emotional episodes in the present while responding to the performance. The practices of the stage-acting styles, directorial conventions, scenography-operate on and transform texts into something with performative force: The text is absorbed into the multifarious verbal and nonverbal discourses of theatrical production, transformed into an entirely incommensurable thing, an event. An act of memory and an act of creation, performance recalls and transforms the past in the form of the present.

Abhinavgupta further elaborates that like the character/actor, the spectator also has identically existing emotions except for the fact they are in latent form. Abhinavagupta attributes the term vāsanā accounting for these latent emotions. For him, vāsanās are impressions in the human mind which are caused by previous experiences or even previous births. They are regarded by Abhinavagupta as being the necessary condition for the spectator to feel a sense of identicality with the emotions suggested in the drama or poetry performed. Professor P.V. Kane writes in this regard that there is in the mind a latent impression of feelings which we once went through, and this is roused when we read a poem which describes similar things. By universal sympathy or community of feeling, we become part and parcel of the same feeling and imagine ourselves in that condition. Thus, the feeling is raised to a state of relish called rasa, in which lies the essence of poetic enjoyment (Kane). 
Attribution takes place through the actor/character/performer who is an integral part of the performance and reconstitutes the text in emotional spaces of the spectators evoking sthayibhavas. At the same time these artists performing themselves while performing are actively involved in experiencing, adapting, transporting, transfer the emotions to the audience resulting in rasa experience. According to the Rasa theory emotions exist in the character and the audience in the form of sthayibhavas: hasahasya rasa / rati-shrangar rasa/ vismaya- adbhut rasa/ jugupsa -vibhatsa rasa /utsah-veer rasa. The Rasa Theory is about the potential of emotions to induce certain states of mind in the audience/the spectators and the performers. I propose the extension of this potentiality to the performativity of the drama circumscribing character, plot, and performer/actor with the language component being subsumed in the performance where character/actor being the charioteer of emotions transmits, translates those emotions understood and experienced by him/her to the audience inducing a particular state of mind. Moreover, the universality of these emotions (sadharanikaran) is what makes possible a disinterested enjoyment rather than a personal involvement.

To conclude, the generation of rasa is dependent on feeling a sense of identity with generalized emotions. These generalized emotions are what Abhinavagupta calls sadharanikaran. However, it is not through understanding the character's emotions in relation to oneself that generalization happens. To be more specific it consists of directly realizing the "universal and impersonal" as opposed to the "particular and individual" that brings identification about. The relishing of Rasa occurs when the performance is shared, translated, internalized as a communicative experience which further exalts the receiver to an exalted state of mind directed by previous personalized experiences of life. Relish of Rasa may also occur in the general form of poetic experience without getting personally attached with the possibilities that in both the instances Rasa will not be the same. Through rasa, one is now allowed to take delight in emotions without the obstruction of their personal/individualistic character. An appropriate end to this discussion is a quote from the Bengali poet Tagore, in speaking of rasa he comments: "...we love to feel even fear or sorrow if it is detached from all practical consequences (Ghosh, 2018)." 
Towards Excellence: An Indexed, Refereed \& Peer Reviewed Journal of Higher Education / Dr. Anshu Surve/ Page 17-26

Both, Performance theory and the tenets of aesthetics evolve in their respective cultural contexts conforming that performances and the consequential aesthetic delight can be characterised as universal, generalised and at the same time individualised too. 


\section{Works Cited}

Ahmed, Sarah. The Cultural Politics of Emotion. Edinburgh: 2004.

Austin, J. L. How to Do Things With Words. Oxford: Clarendon Press, 1962.

Barlingay S S, A Modern Introduction to Indian Aesthetic Theory: The Development from Bharata to Jagannaatha Paperback, 2007

Bharata, Muni, and G R. S. Iyengar. Natyasastra: Translation of Bharatha Natyasastra. Bangalore: Suvani Prakasana, 1977. Print

Butler, Judith. Excitable Speech : A Politics of the Performative. New York: Routledge, 1997

Devy, G N. 2nd Edition. Indian Literary Criticism: Theory and Interpretation. Hyderabad: Orient Blackswan 2010.

Dixon, Thomas. From Passions to Emotions: the Creation of a Secular Psychological Category. Cambridge University Press, 2006.

Ghosh Ranjan K, Essays in Literary Aesthetics. Singapore Springer 2018

Goffman, Erving. "The Presentation of Self in Everyday Life." The

Presentation of Self in Everyday Life. New York: Doubleday, 1959.

Higgins, Kathleen Marie. An Alchemy of Emotion: Rasa and Aesthetic Breakthroughs The Journal of Aesthetics and Art Criticism, vol. 65, no. 1, 2007, pp. 43-54. JSTOR, www.jstor.org/stable/4622209. Accessed 17 May 2020.

Kane, Pandurang Vaman, History of Sanskrit Poetics, 1962, print

Kulkarni, V.M. Outline of Abhinavgupta's Aesthetics. Ahmedabad: Ashwin Kumar B Shah, 1998. Print.

Madison, D. Soyini and Judith Hamera, eds. The Sage Handbook for Performance Studies. SAGE 2006

Mishra, Hari Ram. Theory of Rasa in Sanskrit Drama. Chhatarpur: Vindhyachal Prakashan, 1996. Print

Nathan Stucky and Cynthia Wimmer, eds., Teaching Performance Studies, Southern Illinois University Press, 2002.

Pathak, R.S. Comparative Poetics. 1. New Delhi: Creative Books, 1992. Print.

Phelan, Peggy. Unmarked: The Politics of Performance. London; New York:

Routledge, 1993 
Schechner, Richard. Foreword: Fundamentals of Performance Studies, An Introduction London: Routledge, 2002.

Sedgwick, Eve Kosofsky. Touching Feeling: Affect, Pedagogy, Performativity. Duke University Press, 2006.

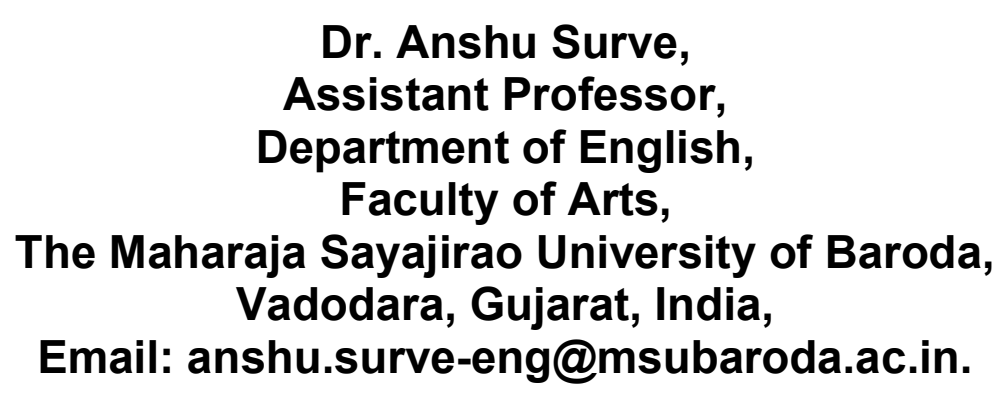

